\title{
Russians' Perceiving The Halal As A Sign Of Quality (Case Of St. Petersburg Meat Market)
}

\author{
Vitally Ivanovich Cherenkova*, Samira Ali Kyzy Musayevab \\ a Department of Marketing, Graduate School of Management, St. Petersburg State University, 199004, Volkhovsky per., 4, St. Petersburg, Russia. \\ b Department of International Master's Degree Programs, National Research University of Information Technologies, Mechanics and Optics (ITMO \\ University), 197101, Kronverkskiy pr., 49, St. Petersburg, Russia. \\ *Corresponding Author Email: cherenkov@gsom.pu.ru
}

\section{Doi: 10.2478/mjhr-2020-0012}

\begin{abstract}
:
There is a lot of scandals and even food poisoning caused by consuming poor-quality meat in Russian Federation (RF). This is especially true for ready-toeat meat products (e.g., sausages, smoked meats, dumplings, meat pies), as the buyers do not see what they are made of. The fact is that in the USSR they had a well-developed system of state verification and standardization of all food products. The state standards (GOSTs) issued for each food product had the power of law. Violations of GOST requirements were regarded as crimes. However, the RF Law "On Standardization" has factually lostits power in connection with the adoption (2002) of the Federal Law "On Technical Regulating". Therefore, new GOSTs have not previous power and are removed from the jurisdiction of the RF government. The fuzzy "technical specifications" (TUs) in contrast with previous severe GOSTs for food do notprovide products quality control butare only indicators of biological, chemical and radiation safety. Using GOST labelling on food items seems as a marketing gimmick today. Nevertheless, recently there have been reports of the development of digital quality control and related legislation. Research findings presented herein show significant growth of Halal meat market. Increased customer confidence in Halal products is also found among non-Muslim buyers. The Council of Muftis of RF, together with the presidential administration of RF, has initiated the development of the state document "Requirements for producing, manufacturing, processing, storage and sale of Halal products". Halal labelling was developed and approved and Halal stores opened. Our brief customer survey has showed the results of customer confidence in the Halal meat and meat product market could be found across the entire range of Halal food items. Taking intoaccount global trends, the Halal food market in Russia as wellas Halal industry as a whole have great prospects (exporting Halal items included) and this phenomenon demands a future extended research.
\end{abstract}

\section{Keywords: food poisoning; GOSTs; Halalmeatmarket; technical specifications}

\subsection{Introduction}

There are the following main reasons inspiring such a growing interest to Halal meat products as well as all Halal food stuffmarket in contemporary Russia. To define these reasons is especially of interest because this research is focused on the positively perceived halal items on meat and meat productmarkets in megacities such as Moscow and St. Petersburg). On the one hand, it is necessary to highlight that during so-called post-Soviet period a unique phenomenon on the Russian food stuff market has been arisen. The matter of fact was that until 2002 the special and severe inherited from the Soviet erastandards existed in "new" Russia (the standards well-known for those who are skilled in the Art as GOSTs - "GO" means "state" and "ST" means "standard" in this acronym). These standards or GOSTs were to be applied to all FMCG products (food stuff category, especially) and the said GOSTs were obligatory to respect. In other words, the GOSTs had the force of law. Violating these standards was considered a criminal offense. However, instead previous GOSTs of the Soviet Union, the Federal Law of theRussian Federation "On the quality and safety of food products" had been adopted in 2000. The term "quality" was used therein 112 times in the said law but the term "standard" was neither defined nor included, absolutely. This law was supplied with special standard «Specifications on food stuff» (known also under the acronym TU - "technical conditions"). It seems that according to the text of the Section 5.2. - "Quality and Safety Requirements" - of the said TU, it is a manufacturer who initially defines the said requirements and the main manufacturer's focus of attention and responsibility is done on safety but not quality of food stuff items. Finally, the Federal Law "On Technical Regulating" hadbeen adopted in 2002. Therefore, the clear and well-understoodGOSTs of USSR for food stuff were mainly substituted by the fuzzy TUs have been developed and approved at manufacturers' level with periodical applications of a sort of rather weak federal/regional supervising. Such a decline in government regulation had gone to the wellperceived deterioration of quality control applied to food stuff items. Today's Russian media have been overwhelmed with information concerninglow qualityand differentfalsificationsonfood stuffmarkets. To understand how acute this problem is in Russia, it is quite sufficient just read the following titles of periodical TV shows: "Natural Selection" (https://namtv.ru/tv/estestvennyj-otbor/) which title has a clear allusion to the wellknown Charles Darwin work; “Food, Dead and Alive One" (https://eda.show/); "Risk Zone” (http://zonariska.su/); are "What we eating?" (http://www.uitv.ru/video/we_eat/); etc. Russian consumers are now searching for adistinct criterion (and a sign or symbol) of quality and safety for their food stuff.

A shift of focus from consumers' emotion on TV screens and in Internet toward scientific works has shown almost the same alertness [1-3]. The problems with defining microbiological, physical and chemical indicators of safety of meat products have been revealed. The violations in the indicators of CMAFANM (mesophilic aerobic and facultative anaerobic microorganisms) and BGKP (coliform bacteria) were found in 65\% of meat samples have been tested. These indicators could indirectly testify violations of sanitary, hygienic and technological conditions on stages of production and distribution of meat and fish products. In general, the falsification of meat and fish products has been categorized as following: assortment, qualitative, quantitative, informational, cost one and any combination of all above said. Such problems are factually common for all countries and overcoming these ones is in the frame the Goal 2 of sustainable development [4,5]. However, they say, levels of food fraud in Russia far exceed relevantindicators found in leading developed countriesand reach up to $50 \%$ and even more than $70 \%$ for sausages and smoked meats and canned meat, respectively [6]. Therefore, Russian people, consciously or unconsciously, seek to find confidence indicators of foodquality.

One of the ways in searching for a suitable indicator could be realized with the help of so called private labels - creating a category "products under private labels, PPL" - that are very popular abroad and are on the stage of fast development in Russia. The Nielsen 2018 data has demonstrated that market share for PPLs increased in 12 of 19 countries were under consideration, and reached up to 30\% or above in 17 countries; in particular, United Kingdom, Germany, Belgium and Portugal - more than 40\% (Private labels on Russian Market, 2018). Since PPLs have been introduced therein far later than in developed countries, the share of PPLsinvolved in retail sales on Russian market is much smaller.Therefore, this indicates that there is a significant room for introducing additional PPLs on Russian market. However, despite the fact that retail chains invest heavily in improving the quality of PP Ls, such products are associated among consumers with «low-cost or tolerable products at a low prices» and this assessment is rather firmly anchored in the perception of many buyers as a trade-off between price and quality. Therefore, the purchases of such perceived as high quality goods present a certain perceived riskfor consumers compared to purchasing other well-advertised brands (or products under manufacturer brands - PMBs) [7]. 
On the other hand, it is very important for better understanding the Halal trend on contemporary Russian meat and meat product market to understand the place and role of the Muslim religion and number of Muslims in Russia. Russia is multinational (more than 160 nationalities) and multi-confessional country (Orthodoxy - 75\%; Islam - 5\%; Catholicism - 1\%; Protestantism - 1\%; Judaism - 1\%; Buddhism - 1\%; other 16\% of Russian population profess other religions, or they cannot determine their religion or are convinced atheists). Historically, Muslim consumers are distributed throughout Russia. However, there are some regions with especially high concentration of Muslim people (Table 1).

Table 1: Distribution of Muslim population in Russian regions

\begin{tabular}{|l|l|l|}
\hline Name of region & $\begin{array}{l}\text { Share of Muslims in the regional } \\
\text { population (\%) }\end{array}$ & $\begin{array}{l}\text { Muslim population } \\
\text { (thousands) [rank] }\end{array}$ \\
\hline Ingushetia & 98,0 & $458[6]$ \\
\hline Chechnya & 96,0 & $1,058[4]$ \\
\hline Dagestan & 94,0 & $2,430[1]$ \\
\hline Kabardino- Balkaria & 70,0 & $535[5]$ \\
\hline Karachay- Cherkessia & 63,0 & $276[8]$ \\
\hline Bashkortostan & 54,5 & $2,234[2]$ \\
\hline Tatarstan & 54,0 & $2,040[3]$ \\
\hline Adygea & 27,0 & \\
\hline Astrakhan Rn & 26,0 & $260[9]$ \\
\hline North Ossetia & 21,0 & $150[10]$ \\
\hline Orenburg Rn & 16,7 & $365[7]$ \\
\hline Khanty-Mansi AO & 15,0 & $216[11]$ \\
\hline Ulyanovsk Rn & 13,0 & $180[12]$ \\
\hline Chelyabinsk Rn & 12,0 & $425[13]$ \\
\hline Yamal-Nenets AO & 11,5 & $140[14]$ \\
\hline Tyumen Rn & 10,5 & \\
\hline Kalmykia & 10,0 & \\
\hline Udmurt Rc & 7,6 & $190[15]$ \\
\hline Altai Rc & 7,4 & \\
\hline Stavropol Kr & 7,0 & \\
\hline
\end{tabular}

Legend: Rn -Region; AO - Autonomous Okrug (district); Rc - Republic; Kr - Kray (very large area).

Source: https://islam- today.ru/islam_v_rossii/dvadczatka_samyx_islamizirovan nyx_regionov_rossii/

A contemporary popularity of Halal products amongRussians (Non-Muslim consumers included) can serve as an example of a specific Halal-driven consumer behavior. They demonstrate their need to have sign and guaranty of quality and safety even with the help of such non-government and formerly exotic symbol as Halal. Recently (September, 2019), it was announced by experts that one of the drivers of Halal marketgrowth is based on the increasing popularity of Halal-branded products among secular or non-Muslim consumers [16]. Since 2008, there are (figure 1) special Halal signs in Halal stores and on packaging of Halal items in all stores where such items are sold. To avoid Halal falsifications the issuance and registration of these signs (badges, stickers) is under the control of the International Center for Halal Standardization and Certification under the Muftis Council of Russia (since 2011) [9].

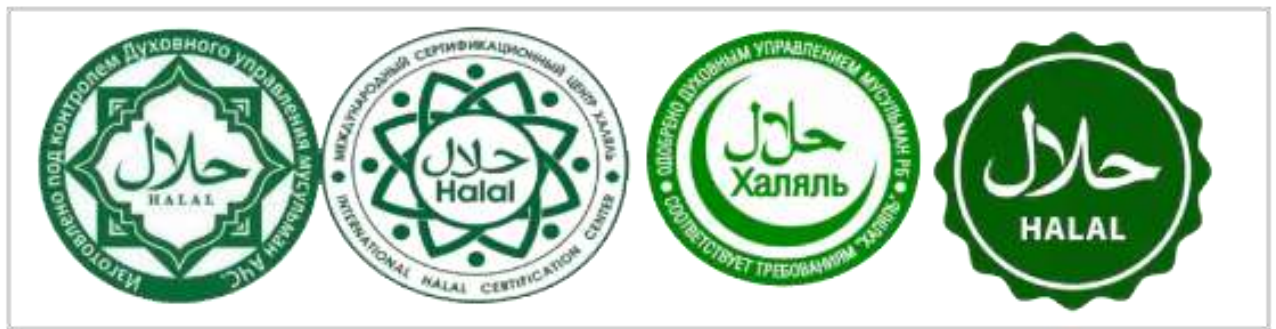

Figure 1: Some Halal signs used in contemporary Russia to mark Halal items

The sources of such popularity of Halal principles are associated with the attitude of the entire population of Russia towards the Muslim religion. As it was defined: (1) Islam did not concentrate on filling the mind with philosophical knowledge, as the Greeks did; (2) Islam did not concentrate on overemphasizing spirituality, as the Indians did; (3) Islam did notconcentrate on physical education, as the Romans did; (4) Islam did not begin to concentrate on materialistic philosophy pursuing the mercenary goals, as is done in the present materialistic world equally in the East and in the West, but developeda balanced and perfect plan for the education of man, taking into account the needs of his body, mind and spirit [11]. Thisprovision has been repeatedly mentioned in Russian works on the reasons of high importance and attractiveness of Muslim culture for the non-Muslim population in Russia [10,12,15]. By reading articles like the above, one can understand the very important role of Islam in the Russian value- semantic and civic space, as well as on historical experience of coexistence of different confessions in the same country (see the percentage distribution above). Historical roots of this phenomenon are partly in the history of so-called "inner colonization" in Russia where Russian metropole - unlike European and British colonization - was comparatively much more tolerant to the non-orthodox confessions in Siberia [14]. And since the reign of Catherine, the Second (1762-1796), attitude towards Muslims and their culture in Russia had become very loyal [17].

The contemporary revival of Islamic values in Russia can be indirectly estimated by the dynamicsofthenumberofmosques. The Chairman of the Council of Muftis of Russia Ravil Gainutdin noted: "The growth in the number of mosques most clearly reflects the process of Islamic revival in Russia [18]. If by the mid1980s, less than 100 mosques were operating on the territory of the RSFSR former name of the territory of contemporary Russia], now their number has exceeded 7 thousand". In our opinion, this is weighty evidence in favor of all-Russia distribution and strengthening the influence of Islamic values in Russia, among which the respect for the notion of halal takes place. Some information presented on Figure 1 - pics with Mosques have been erected in Russia in $20^{\text {th }}$ and $21^{\text {st }}$ century, respectively, serves to support our opinion concerning the new time of the revival of Islam in Russia. 
Besides, our fast and cheap study effectuated on central streets of the city of Saint- Petersburg had shown a general positive attitude to Islam values, Muslims and Halal. However, among 200 respondents (first filtering question was "Are you a Muslim?" and after "Yes" it was the last one) 173 ones gave their more or less full answers: those who had a positive attitude to Muslims and their culture - 76\%; those who heard about / read the Quran - 100\% / 2\%; those who heard about / knew the Halal rules - 92\% / 24\%. More positive attitude was revealed among Russian women. Judging by their statements (after formal questions), Islam attracts Russian women with demands for cleanliness and rejection ofalcohol.

We consider the arguments above quite sufficient to suppose that our hypothesis concerning the role of Halal sign on the meatand meat product market (or on the B2C marketas a whole) has a chance to be confirmed. Moreover, there are enough opinions in the Russian press in favor of this hypothesis. For example, the President of Russian Agrifood Strategies Co. Albert Davleev has defined that the share of Halal products approaches $100 \%$ of the total meat market in the republics of the North Caucasus (Russia) [18]. An important conclusion on the prospects of a halal market was made by the chief analyst of Cherkizovo Co. (Moscow) Andrey Dalnov [ibid.]: "Halal has its own understandable audience - Muslims and people who are not directly related to Islam, but tend to buy products made with special attention or additional control".

Concluding the Introduction herein, we would like to note that the concept of Halal in the practice of trade (or, more broadly, in applications throughout the entire supply chain) could be used as a marketing gimmick only. One says "Halal meat as is understood these days is a term used more often for commercial profits than religious observance" [19]. It could be an item of competiveness because those who call their meat Halal, "are in some way insinuating that any other meat is not halal, or specifically that other meat sold in other butchers or supermarket (in the western countries) is not Halal" [ibid.].

However, while searching for a Halal food definition in the surahs of the Quran nobody could find any verse with a formal Halal food definition. It is not a question of definition but it is a matter of true faith and appropriate behavior for all nods included into a supply chain for Halal food stuff. We would like to repeat at the end that "the moral equity of a Muslim salesperson would not be a relative term but an absolute and non- ambiguous term, based on Quranic commandments and Islamic principles what is permissible (Halal) and non- permissible (Haram)" [20].

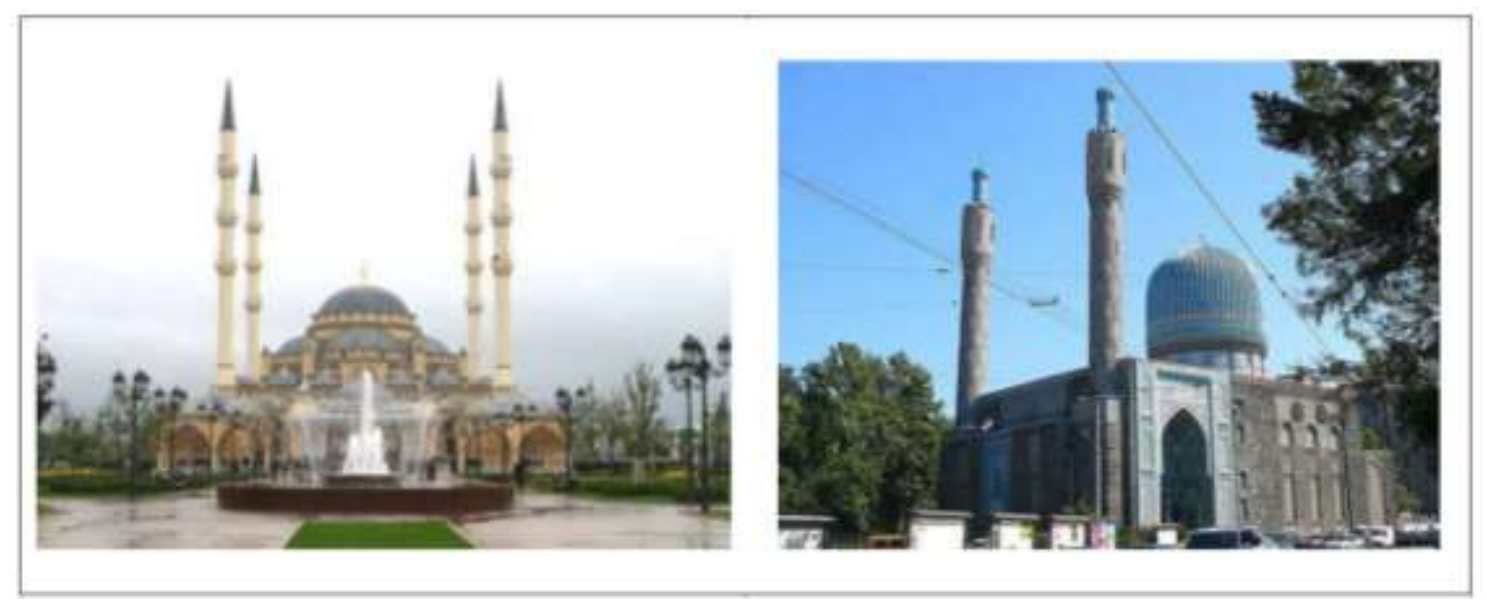

Figure 2: Left-side pic: TheSt. Petersburg Cathedral Mosque (11th place among the largest Islamic temples in Europe; height of minarets-48m, height ofdome$39 \mathrm{~m}$ ), accommodating up to 7 thousand believers, had been erected in Saint-Petersburg (Russia) in 1910-1913 period. Right-side pic: The largest Mosquein Europe "HeartofChechnya" namedaftertheprophetMuhammad(heightofminarets-62m, height of dome-32 m)), accommodating up to 30 thousand believers, hadbeen erected in Grozny (Russia) in 2006-2008period.

Table 2: Two-dimensional segmentation of the St. Petersburg Halal meat and meat products market

\begin{tabular}{|c|c|c|c|c|c|c|c|}
\hline & & \multicolumn{6}{|c|}{ Consumer clusters** } \\
\hline & & True Muslims & lowers of Islam & $\begin{array}{l}\text { Healthy } \\
\text { Food Advocates }\end{array}$ & Foodies & \begin{tabular}{|l|} 
Exotic Food \\
Lovers
\end{tabular} & \begin{tabular}{|l|} 
Random \\
Halal Consumers
\end{tabular} \\
\hline \multirow{4}{*}{$\begin{array}{l}\text { Reasons for } \\
\text { consumer } \\
\text { appealing to } \\
\text { the Halal meat } \\
\text { and meat } \\
\text { products } \\
\text { market** }\end{array}$} & $\begin{array}{l}\text { Following the } \\
\text { nciples of Islam }\end{array}$ & $13 \%$ & $17 \%$ & $26 \%$ & $14 \%$ & $10 \%$ & $14 \%$ \\
\hline & $\begin{array}{l}\text { rception of Halal } \\
\text { as a } \\
\text { quality mark }\end{array}$ & $34 \%$ & $57 \%$ & $23 \%$ & $12 \%$ & $47 \%$ & $28 \%$ \\
\hline & \begin{tabular}{|l|} 
Conspicuous \\
consumption
\end{tabular} & $22 \%$ & $52 \%$ & $33 \%$ & $12 \%$ & $16 \%$ & $12 \%$ \\
\hline & $\begin{array}{l}\text { Perception of } \\
\text { Halal meat } \\
\text { products as more } \\
\text { delicious } \\
\text { ones }\end{array}$ & $27 \%$ & $29 \%$ & $25 \%$ & $6 \%$ & $29 \%$ & $20 \%$ \\
\hline
\end{tabular}

Legend: * - e.g., Non-Muslim members of Muslim families and/or simply adherents of Islam in St. Petersburg; ${ }^{* *}$ - the both clusters have been formed as a result of formalization of the received questionnaires

Source: compiled by the authors on the basis of the research that outputs are presented herein.

\subsection{Methodology}

There are two methodological approaches used herein to define the state of the Art and the perspectives of development the Halal meat and meat product market in Saint- Petersburg. The said city was chosen as the object of this research, because the non- Muslim residential population in large cities is more prone to changing traditional patterns of consumer behavior than in small cities and rural areas.

The first methodological approach matches to using so-called lead-lag principle that could be applied to the case under consideration due to the fact that the Halal market abroad is much more developed than the similar one in Russia [21]. The worldwide market for Halal Food is estimated about US\$1,14 Bn in 2019 [22]. In other source the global Halal food market was valued at US\$ $715.0 \mathrm{Bn}$ in 2018, and is projected to exhibit a CAGR of $12.7 \%$ over the forecast period (2019- 
2027), in terms of revenue [23]. Besides, a set of relevant academic articles has been analyzed to get to understanding main concepts and methods of analogue research done in Muslim countries mainly [24-28].

The second methodological approach is based on traditional marketing tools applied for market research to collect primary data (field research and online survey) and then to process them statistically (with help of the Statistical Package for the Social Sciences - SSPS soft) with further expert interpretation.

\subsection{Materials}

The object of research has been defined as following: (1) geographical area - St. Petersburg (Russia); (2) product - meat and meat items; (3) target market consumers characterized by: (a) meateaters - regular meat consumption; (b) confession - Muslims and Non-Muslims, both clusters included; (c) age - 21- 60 (this interval is defined as: infimum - average age for entering in independent economic activities in Russia; supremum - the threshold for women to become retiree in Russia). General composition or population taking into account consumers' confessions could be characterized with help of data in the Table 3. The same data served to normalize the sampling collected to be statistically processed. The sampling under consideration had 268 filled enquires but after comparing with the general composition final number of enquires was reduced to $204.44 \%$ and $36 \%$ of respondents called themselves Christians and Muslims, respectively; $19 \%$ atheists; $1 \%$ - Jews. Despite the serious discrepancy between this composition and the data in the Table 3, we suppose that the sampling corresponds equally to the real proportion of Christians and Muslims in St. Petersburg.

Table 3: Distribution of Saint-Petersburg believers by main confessions (2018)

\begin{tabular}{|l|l|l|}
\hline Name of confession & $\begin{array}{l}\text { Share of Saint- Petersburg population } \\
(\%)\end{array}$ & Number of believers (thousands) \\
\hline Adult habitant & $\mathbf{1 0 0 , 0}$ & $\mathbf{4 , 3 3 0}$ \\
\hline Atheists & $\mathbf{5 , 0}$ & $\mathbf{2 1 6}$ \\
\hline Undecideds & $\mathbf{3 5 , 0}$ & $\mathbf{1 , 5 1 6}$ \\
\hline Believers & $\mathbf{6 0 , 0}$ & $\mathbf{2 , 5 9 8}$ \\
\hline Orthodoxy & 57,5 & 2,490 \\
\hline Islam & 0,7 & $30^{*}$ \\
\hline Protestantism & 0,6 & 26 \\
\hline Catholicism & 0,5 & 22 \\
\hline Buddhism & 0,1 & 4 \\
\hline Others & 1,2 & 52 \\
\hline
\end{tabular}

Legend: *- According to data of Mufti Jafar Ponchaev - 800,000 (https://www.fontanka.ru/2010/04/12/075/); Source: calculated by the authors on the basis of: https://piterbu.ru/pozitiv/6686-chislennost-naseleniya-sankt- peterburga-na-2017-god-ego-sostav-i- natsionalnosti.html and https://okinform.ru/obshchestvo/5554-religioznoe- litso-peterburga.html

There are no special Halal statistics concerning St. Petersburg Halal market. However, using an indirectapproach it was possible extrapolate the expertassessment made in 2014 for the year 2018 and receive an average size of this market equal to $\$ 160 \mathrm{mln}$ [29]. However, we doubted the accuracy of this market size indicator. So, given the predictive nature of the present study, we were forced to turn to assessing the potential demand for Halal meat and meat product in St. Petersburg. As a result, potential of any meat and meat products market in St. Petersburg in 2018 could be assessed as $\$ 2,0$ bln. Halal meat market background shows that supply/demand balance is seriously distorted: it turned out that most of all the lack of halal products is felt in such retail networks as Magnit (24\% of respondents), Pyaterochka (20.5\%) and Auchan (17.4\%) [16]. Therefore, Russian Halal meat industry has good opportunities for further development.

\subsection{Methods}

To identify the most visited retail chains by consumers in order to buy meat products, as well as retail chains where Halal meat products were most often revealed, dummy variables (with meanings 0 or 1 ) were created that were used to encode questions: "In which of the following retail chains do you most often buy meat products?", "In which of the following retail chains have you noticed halal meat products?", "What kind of halal products did you notice?", "In what sources do you look for information concerning meat products before buying them?".

Table 4: Title and nature of latent variables

\begin{tabular}{|c|c|}
\hline Title of latent variable & $\begin{array}{l}\text { Example of latent variable and [number of them used in } \\
\text { research] }\end{array}$ \\
\hline Halal knowledge & I understand the meaning of such concept as "Halal" [3]. \\
\hline Quality benefits & $\begin{array}{l}\text { I consider that the quality of Halal meat products is higher than } \\
\text { that of conventional meat products [4]. }\end{array}$ \\
\hline \begin{tabular}{|l|} 
Religious \\
perception
\end{tabular} & $\begin{array}{l}\text { When buying Halal meat products I } \\
\text { emphasize my commitment to the Islam [4]. }\end{array}$ \\
\hline $\begin{array}{l}\text { Skepticism toward Halal } \\
\text { claims }\end{array}$ & $\begin{array}{l}\text { In most cases, the information on the packaging of a Halal meat } \\
\text { product misleads the consumer [4]. }\end{array}$ \\
\hline \begin{tabular}{|l|} 
Consumer \\
behaviour
\end{tabular} & $\begin{array}{l}\text { In the future, I will start buying Halal } \\
\text { meat products [5]. }\end{array}$ \\
\hline $\begin{array}{l}\text { Willingness to pay a price } \\
\text { premium }\end{array}$ & $\begin{array}{l}\text { Sometimes, in order to save money, I buy food of not the highest } \\
\text { Quality [4]. }\end{array}$ \\
\hline $\begin{array}{l}\text { Quality } \\
\text { importance }\end{array}$ & $\begin{array}{l}\text { I always strive to buy the best quality } \\
\text { Food [5]. }\end{array}$ \\
\hline Taste importance & I can neglect the price, but buy a more delicious meat product [5]. \\
\hline Attention to marking & I often review the ingredients of a product before I buy it [3]. \\
\hline Environmental concern & $\begin{array}{l}\text { It is important for me that animals receive the lowest level of } \\
\text { stress during slaughtering [4]. }\end{array}$ \\
\hline Health consciousness & I have a healthy diet [5]. \\
\hline
\end{tabular}

Along with the creation of dummy variables it was necessary to create a number of latent variables: (1) Halal knowledge; (2) Quality benefits; (3) Religious perception; (4) Scepticism toward Halal claims; (5) Consumer behavior; (6) Willingness to pay a price premium; (7) Quality importance; (8) Taste 
importance; (9) Attention to marking;

(10) Environmental concern; (11) Health consciousness. Table 4 gives an idea of the nature of the latent variables listed above.

In order to assess understanding the term "Halal" by Petersburg consumers and to reveal their attitude to Halal meat products the Google Forms platform was used. The survey consisted of five blocks of questions the purpose of which was: (1) determine how consumers imagine Halal meat products and obtain individual characteristics of respondents as consumers; (2) characterize the behaviour of respondents asconsumers; (3) find out the behaviour of respondents while buying food stuff, in general; (4) clarification of personal views and opinions of consumers; (5) personalies. The analysis of secondary information revealed seven independent variables: (1) Quality benefits; (2) Skepticism toward Halal claims; (3) Taste importance; (4) Religious perception; (5) Health consciousness; (6) Environmental concern; (7) Conspicuous consumption. The dependentvariable is the actual consumption of Halal meat products. After processing the data, it turned out that the following reasons influence the decision to purchase halal meat products to the greatest extent (as their impact decreases): "Conspicuous consumption”, “PerceptionofHalalas aqualitymark”, "Perception of Halal meat products as more delicious”, "Following the principles of Islam”, "Environmental concern", and "Health consciousness".

The verification of the research model according to criteria known to those who are skilled in statistics showed its viability. An analysis of the model predictor coefficients showed that the following predictors were significant (See Table 2): "Conspicuous consumption", "Perception of Halal as a quality mark", "Perception of Halal meat products as more delicious", "Following the principles of Islam".

\subsection{Results And Discussion}

The consumer-respondents mostly noticed Halal meat (about 36\% of respondents), followed by Halal sausages (30\%) and Halal meat semi-finished products (21\%). To a lesser extent, ready Halal meals were noticed (5\%). About $9 \%$ of respondents did not notice halal meat products at all. Consumers mostly noticed Halal meat (about 36\% of respondents), followed by Halal sausages (30\%\%) and Halal meat semi-finished products (21\%). To a lesser extent, ready Halal meals were noticed (5\%).

In order to assess understanding the term "Halal" by Petersburg consumers and to reveal their attitude to Halal meat products the Google Forms platform was used. The survey consisted of five blocks of questions the purpose of which was: (1) determine how consumers imagine Halal meat products and obtain individual characteristics of respondents as consumers; (2) characterize the behaviour of respondents asconsumers; (3) find out the behaviour of respondents while buying food stuff, in general; (4) clarification of personal views and opinions of consumers; (5) personalies.

The smallest correlation $(0,463)$ has been observed for the factor "Trust in halal labelling" (latent variable - "Attention to marking"). Such a result is probably associated precisely with the widespread occurrence of Halal fakes in St. Petersburgand in Russia as a whole as a result of the use of Halal markings by Russian dishonest manufacturers for commercial purposes and, as a result, with the loss of the value of halal markings as such [19]. The predictor "Environmental concern" probably did not have such an impact on the decision to purchase halal meat products due to the fact that not many people are aware of the principles and rules of slaughtering animals according to Islamic standards and how minimally causing stress and pain to the animal when they are killed mean. The least significant factor was "Religious perception" which is most likely due to the consequences of the Soviet era and the preservation of a significant number of atheists in St. Petersburg.

Limited to the already cited results of our analysis of consumer behaviour in the Halal meat products market in St. Petersburg, it is a good time to present some logical considerations. The market for Halal meat products is growing rapidly, which despite the religiosity of its concept, is chosen by many buyers. The halal concept takes on a new character. The Halal began to be seen in Russia as a system of reliable quality control and production of clean, most harmless and highquality products. In other words, the Halal turns into a brand [30]. Comparison with the dynamics of the market of Halal meat products abroad shows that the Russian market, with some delay, shows the same trends. The last but not least consideration concerning Russian Halal industry supported by our analysis of relevant business and academic literature shows good perspectives for exporting Halal meat products from Russia.

Contrary to the quantitative estimates obtained in this study (the predictor "Following the principles of Islam"), the influence of Muslim culture in Russia is increasing. In addition to quantity indicators (Muslim birth rate is much higher; plus strong Muslim migration from former Soviet republics) there are indirect quality indicators: increase in the number of new mosques and madrassas, Islam literature on shelfs of book stores, academic Islam studies, etc. All this allows us to hope for a growing impact of true Muslim ethics not only on consumers, but also on all links of the Halal supply chain. Because, the verse of Quran " $O$ mankind, eat of that which is lawful and good on the earth and follow not footsteps of the devil. Indeed, he is an enemy to you" [Al Quran Surah $2 \mathrm{AlBagarah}$ Verse 168] has to manage not only eating consumer behavior but the Islam ethic of sellers. Because, thinking logically, the nature of consumer behavior usually largely depends on the options offered by sellers.

Finally, Halal principles concerning food stuff are codified in documents issued by such international organizations as FAO, WHO and OIC. For example, the Codex Alimentarius contains the article CAC/GL 24-1997- General guidelines for use of the term "Halal". Russia is a member of FAO and WHO and hasthe status of the Observer State in OPIC as a country with significant Muslim population (according the Census of Population 2002 - about 14, 5 mln.; more than 20,0 mln. in 2015 according non-official estimation revealed in [31].

\subsection{Conclusions}

Studying thecase ofSt. Petersburg Halal meatand meat products marketand reviewing relevant Russian business and academic literature permits, to our mind, to extrapolate the trends highlighted herein and conclude that this market is estimated as very attractive and promising one due to the high growth and migration rates of the Muslim population both in Russia and in the world (export opportunities Russian halal products are assessed as significant). This is because Halal products are perceived as a better product in terms of all nods of so-called Halal supply chain (production, processing, storage, and selling). The Halal certified products are in demand not only among Muslims, butalso among Non- Muslim consumers (from other confessions and atheists). It should be noted that not only Islam values promote Halal products but also a feedback exist - Halal as a brand of high quality promotes a quantum of Islam knowledge. Besides, an accelerated development of the Halal meat and meat product industry under Western anti-Russia sanctions creates two phenomena: (1) growth of export meat items from Russia and (2) good FDI opportunities (e.g., in the form of joint venturing with partners from Muslim countries). However, this marketin Russiais still not sufficiently formed and is on the stage of formation and growth. Therefore, a further research is desirable. It seems that such a research could be more detailed and have applied value (e.g., for strategic investors) with the participation of researchers from Muslim countries.

\subsection{References}

[1] Z.A. Yurchak, N.V. Maslova, and D. Starchikova, "Review of Food Falsifications with Food Additives”, All about Meat, 5, Pp. 14-17, 2016. (in Russian).

[2] S.V. Samoylov, N.M. Suraeva, T.K. Volodarskaya, and N.A. Kireeva, "Safety Assessment of Meat and Fish Products", Bulletin of the Krasnoyarsk State 
Academy of Management, 3, Pp. 161-174, 2019. (in Russian).

[3] A.N. Petrov, R.A. Khanferyan, and A.G. Galstyan, "Current aspects of counteraction of foodstuff falsification”, Issues of Nutrition, 5(86), Pp. 86-92, 2016. (in Russian).

[4] WHO (World Health Organization). WHO estimates of the global burden of food-borne diseases, 2015.retrieved at $07 \quad$ September 2019 at http://apps.who.int/iris/bitstream/10665/199350/1/9789241565165_eng.pdf?ua=1]

[5] Goal, 2. End hunger, achieve food security and improved nutrition, and promote sustainable agriculture, In: The Sustainable Development Goals 2015 - 2030, retrieved at 07 September 2019 at https://una-gp.org/clancyt/files/goals/goal2.pdf.

[6] K.K. Shuklina, "Quality and Safety of Meat and Meat Products", Proceedings of the International scientific- practical conference Using Modern Technologies In Agriculture and Food Industries. April 24-25, 2019, Don State Agrarian University, Pp. 194-196, 2019. (in Russian).

[7] I. Cakmak, "The role of brand awareness on brand image", perceived quality and effect on risk in create brand trust, Selected Papers of 4th World Congress Administrative and Political Sciences (ADPOL-2015) retrieved at $07 \quad$ Sept $\quad 2019 \quad$ at https://sproc.org/ojs/index.php/pntsbs/article/view/, Pp. 441-458, 2016.

[8] The Dairy News, Market players discussed the problems and prospects of the halal industry in Russia, Oct. 7, retrieved at 07 September 2019 at https://www.dairynews.ru/news/igroki- rynka-obsudili-problemy-i-perspektivy-khalya.html(in Russian)

[9] M. Kalimullina, "Why do Russian companies misuse halal certificates?", Russia Mufties Council, October, 14, retrieved at 14 September 2019 at https://muslim.ru/en/articles/133/3865/

[10] O.V. Volter, "Orthodoxy and Islam in the context of statehood of Russia”, Bulletin of the Transbaikal State University, 5(22), Pp. 48-59, 2016. (in Russian).

[11] I. Azam, "Islam and the future". Islamabad: The PFI and Margalla Voices, Pp. 393, 2003.

[12] G. Sabirova, "Muslim identities and the discursive tradition of Islam in post-Soviet Russia, In: Traditions and innovations in modern Russia", Sociological analysis of interaction and dynamics / Ed. Hoffman, 457-495, 2008. retrieved at 13 September 2019 at https://www.academia.edu/6731031 (in Russian).

[13] Private labels on Russian market, Russian food market, 2, retrieved at 07 September 2019 at http://www.foodmarket.spb.ru/current.php?article=2500

[14] A. Etkind, "How Russia 'Colonized Itself", Internal Colonization in Classical Russian Historiography. International Journal for History, Culture and Modernity, 3(2), Pp. 159-172, $2015 . \quad$ retrieved at $13 \quad$ September $2019 \quad$ at https://www.researchgate.net/publication/282413157_How_Russia_'Colonized_Itself'Internal_Colonizatio n_in_Classica l_Russian_Historiography (accessed on 02 October 2019)

[15] M.M. Mchedlova, "Islam and unity of the Russian society: Modernity and historical experience", Islam in the modern world, 1(11), Pp. 93-102, 2015. (in Russian).

[16] The Dairy News. Economist: The supply of halal products does not keep up with demand. The Dairy News, October, 14, 2019, retrieved at October, 14, 2019 at https://www.dairynews.ru/news/ekonomist-predlozhenie-khalyalnoy-produktsii-ne-us.html?type=mobile (in Russian)

[17] D. Arapov, and Yu, "Islamic policy of Catherine the Great", Bulletin of Moscow University. Series 8, History, 5, Pp. 25-37, 2014. (in Russian).

[18] Permitted poultry, A demand on Halal items is growing in Russia and the world, Agroinvestor, June 22, 2019, retrieved at 07 August 2019 at https://www.agroinvestor.ru/analytics/news/31950-razreshennaya-ptitsa/(in Russian)

[19] Halal Meat. The Quranic Truth, 2015. retrieved at 07 September 2019 at https://www.ummah.com/forum/forum/islam/general-islamictopics/470033-halal-meat the- quranic-truth

[20] U. Burki, 2013. An Islamic marketing perspective on salesperson's intentions to behave ethically. International Journal of Social Entrepreneurship and Innovation, 2(5), Pp. 391-403, 2013.

[21] S. Hollensen, "Global Marketing", Pearson Education Limited, 2014.

[22] Halal Food Market, Global Industry Value, Size, Share, Demand, Emerging Trends, Food Ingredients Products, Growth Opportunities, Business and Forecast 2024, 2019, Reuter PLUS, retrieved at 13 September 2019 at https://www.reuters.com/brandfeatures/venture- capital/article?id=96545

[23] Coherent Market Insights, Global Halal Food Market to Reach US\$2,043.2 Billion by 2027. Jun 17, 2019, retrieved at 14 September 2019 https://www.prnewswire.com/news-releases/global-halal-food-market-to-reach-us-2-043-2 billion-by- 2027--coherent-market-insights300869331.html

[24] N.Z.N. Wan, R.A. Bakar, S. Razak, and S. San, "The Importance of Halal to Muslim Consumers: Are They Powerful Stakeholders", Journal of Applied Environmental and Biological Sciences, 4(6S), Pp. 50-55, 2014. retrieved at 06 August 2019at https://www.researchgate.net/publication/31195209 9_The_Importance_of_Halal_to_Muslim_Consumers_Are_They_Powerful_Stakeholders

[25] J. Kasuma, Y. Yacob, and R. Tayo, "Are Non- Muslim consumers understand about Halal principles? : A case of Non-Muslim Bidayuh ethnic in Sarawak, Borneo", 1st International Business Economics Social Sciences Research Association (IBESRA), Istanbul, Turkey, December, 29, retrieved at 14 August 2019 at https://islidedocs.com/document/are-non-muslims- consumer- understand-about-halal-principles-a-case-of- non-muslims-bidayuh-ethnicin-sarawak-borneo

[26] N.A.B. Ahmad, T.N.B.T., Tunku Nashril Bin Tunku Abaidah, and M.H.B.A., Yahya, "A study on awareness of halal food among Muslim customers in Klang Valley", Proceedings of 4th International Conference on Business and Economic Research (4TH ICBER 2013), 2013. retrieved at 14 Augus 2019 at https://www.academia.edu/9229684/A STUDY ON HALAL_FOOD_AWARENESS_AMONG_MUSLIM_CUSTOME RS_IN_KLANG_VALLEY

[27] N. Muhamad, V.S. Leong, and N.M. Isa, "Does the country of origin of a halal logo matter? The case of packaged food purchases", Review of International 
Business and Strategy, 27(4), Pp. 484-500, 2017. https://doi.org/10.1108/RIBS-06-2017-0049

[28] L.A. Halaseh, and B. Sundarakani, "Study on quality attributes of halal food supply chain", International Journal of Logistics Economics and Globalisation, 4(1/2), Pp. 20-34, 2012.

[29] K. Mirzakarimova, The number of stores selling Halal products is growing in St. Petersburg, Business Petersburg, retrieved at 14 Sept 2019 at https://www.dp.ru/a/2014/11/05/Haljalnij_bum

[30] J.A.J. Wilson, and J., Liu, “Shaping the Halal into a Brand?”, Journal of Islamic Marketing, 1(2), Pp. 107-23, 2010.

[31] H.D. Chernomorchenko, Dry statistics - in Russia today there are more Muslims than Orthodox, Voice of Islam, retrieved at September, 15, 2019 at https://golosislama.com/news.php?id=26836 (inRussian) 